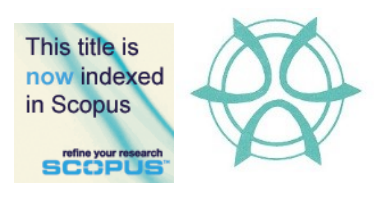

\title{
UNCERTAINTY IN BUSINESS VALUATION FOR TAX PURPOSES
}

\author{
Kristian Agung Prasetyo ${ }^{1}$, Adhipradana Prabu Swasito ${ }^{2}$, Dhian Adhetiya Safitra ${ }^{3}$ \\ ${ }^{1,2,3}$ Valuer Diploma III Vocational Program in Tax Major \\ POLYTECHNIC OF STATE FINANCE STAN
}

\begin{abstract}
An important but often neglected aspect in business valuation for tax purposes is uncertainty. It is known in the literature that changes in economic structure, people's behavior, business risk, or political leader are expected. Unfortunately, these factors cannot be effectively measured and reported in business valuation for tax purposes. As such, most business valuations for tax purposes are unable to capture uncertainty adequately. Valuation reports under a tax investigation process only present an estimated value in the form of a single value, which is unable to represent uncertainty sufficiently. This paper aims to demonstrate a method to quantify uncertain variables into the business valuation for tax purposes. The research engaged scenario analysis to arrive in three different possible value estimates, and Monte Carlo simulation to take uncertainties into accountto produce a frequency distribution containing all possible values between predetermined limits. Using the range of value produced in the simulation, a taxpayer will have more complete information to decide whether taxpayers submit an undervalue report or not.
\end{abstract}

Keyword: Business Valuation, Tax, Scenario Analysis, Monte Carlo JEL Code: G170

\footnotetext{
${ }^{1}$ Lecturer at Polytechnic of State Finance STAN. Email: kagungp@gmail.com
} 
Kristian Agung Prasetyo, Adhipradana Prabu Swasito, Dhian Adhetiya Safitra

Uncertainty In Business Valuation: The Monte Carlo Approach

\section{INTRODUCTION}

In the business context, valuation is aims to work our the total market value of a company (Sinem and Saad (2020) for various purposes, including commercial transactions, financing, taxation, bankruptcy, and ownership transition. While the value of physical assets is generally known, the overall market value of a business is often unknown because market value is merely an estimate of sale price in the open market between willing buyers and sellers (Sayce et al., 2009), and the summary of the company's net assets and goodwill (Fernandez, 2007). The primary assumption is that this interaction occurs in an open market between willing buyers and sellers. The current standard defines market value as the predicted amount of an asset at the valuation date after proper marketing, which each party has acted knowledgeably, prudently, and without compulsion (IVSC, 2010). Accordingly, an accurate estimation of market value is desirable as it leads to a better decision making (Ja'afar \& Muhammad, 2021).

These definitions generally say that the company's value is the result of estimation or prediction. the estimated value may be different from the actual price when a transaction occurs. In fact, it is common to find discrepancies in estimated market values reported by one appraiser from another, which Mohammad, Mohd Ali, \& Haryati Jasimin (2018) as the art of valuation. Valuation is a mere attempt to predict prices that might occur in transactions., it carries an element of risk or uncertainty inherent in its process.

In the context of Indonesia's income taxation, business valuation has become increasingly important. For instance, profits from selling shares in corporate actions (e.g., mergers or acquisitions) or selling a company above the fair value are subject to income tax. However, the integrity of income tax system is undermined by taxpayers who defensively file an underreport in transaction values (Allingham and Sandmo, 1972). Meanwhile, tax valuers (tax officers who primarily performs valuation for tax purposes) strives for measuring as accurate transaction values as possible.

The effect of risks faced by Indonesian tax valuers compounds as taxpayers often do not provide an actual transaction amount. This situation makes tax valuers are unable to produce adequate report of the market value for the given transactions. As a result, the outcome of a valuation process contains a degree of uncertainty. However, the uncertainty is not fully covered in business valuation reports for tax purposes in Indonesia because the reports only provide a single value estimate. Accordingly, this paper aims to fill this gap by demonstrating the method of incorporating uncertainty in the business valuation process. For this purpose, this paper is organized as follows. Section II describes a brief literature review on valuation and the Monte Carlo approach. Section III demonstrates how uncertainty is incorporated into the valuation. Finally, the fourth section identifies several limitations with regard to the methods chosen in this paper. A brief conclusion at the end concludes this paper. 
PLANNING MALAYSIA

Journal of the Malaysia Institute of Planners (2021)

\section{LITERATURE REVIEW}

\section{Uncertainty in Business Valuation}

As a process of estimating the value of an asset, valuation is a mere expert opinion (French and Gabrielli 2004) that produces a series of price estimates based mainly on certain assumptions instead of facts (IVSC 2010). Kummerow (2002, p. 408) states that statistically, a value estimate contains:

1. Estimated parameters (average) of various possible prices that are most likely to occur.

2. The estimated error of the parameters calculated in number 1, which, for example, is measured using standard deviations.

3. Estimated stability of the estimated parameters above in the future.

4. Assumptions used to calculate various estimated parameters above.

To calculate the estimated value, a valuer constructs a valuation model which, according to French (2004, p.535) and Field (2017), replicates events that occur in the real world. Naturally, the output of the model may not fully resemble the actual state. If an asset is traded, the valuer must prepare valuation model to estimate the most probable price and reflect the actual market conditions to produce a valid estimation (French 2004: 534). Typically, such model is constructed using variables obtained from comparables.

A good model is one with a minimum error. An accurate model output has a high fitingness (Lincoln and Guba, 1985) or similarity between the results of the model and the actual transaction price. However, since such model is difficult to obtain, predictions based on a valuation model must be adjusted so that the estimates would reflect the actual transaction price more accurately. This might raise a question of whether the appraisal has been carried out correctly (Emirzon, 2005).

Generally, uncertainty can be illustrated as a continuum, (Figure I) (van Vuuren, 2017: 230). The first condition - certainty - is an ideal condition in which all economic principles apply perfectly. For example, both sellers and buyers always act rationally with an ultimate goal of maximizing profit or utility (Jansen van Vuuren 2017: 232). In business valuation, certainty happens when reasonable comparative data are widely available and easily accessed by sellers and buyers. As a result, all valuation approaches can be used with relatively accurate results.

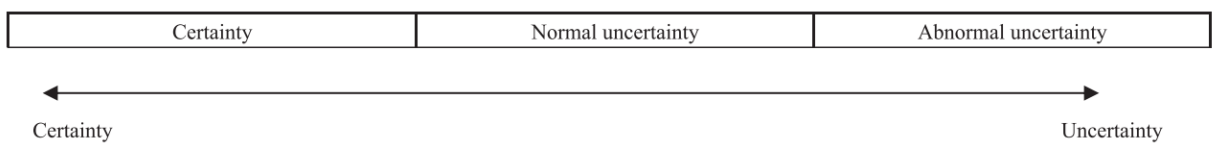

Figure 1: Uncertainty Continuum

Source: Jansen van Vuuren (2017: 230)

However, ideal condition is relatively rare. In reality, information is often asymmetric as one party generally knows more than the other, thus creating 
Kristian Agung Prasetyo, Adhipradana Prabu Swasito, Dhian Adhetiya Safitra

Uncertainty In Business Valuation: The Monte Carlo Approach

uncertainty in values estimation as either normal or abnormal uncertainty (Figure 1). Meanwhile, the typical uncertainty is the most common situation faced by valuers (van Vuuren, 2017) where asymmetric information flow is the norm. Parties with better access to information, such as data transactions tend to have a competitive advantage over the others. Consequently, comparable data transactions become limited and the valuers' subjectivity and judgment become more critical. As such, the valuers must adjust valuation approach, to not simply increase the accuracy of the assessment results, but rather provide a more comprehensive picture to the users of the valuation report. This condition can be seen, for instance, in the widely-used Discounted Cash Flow (DCF) technique.

DCF is not without weakness, and concerns have been raised on its use (Laughton, Guerrero, and Lessard, 2008; Bancel and Mittoo, 2014). Previous findings reported that DCF ignores risk and uncertainty and, therefore, may misjudge investment with non-linear returns. Further, DCF uses a single discount rate in the discounting process, regardless of risk or financing differences (Nowak and Hnilica, 2012). In fact, DCF can mostly associate its usefulness in understanding a company's average value without taking into account the risks and uncertainties that should have been built in the model.

As it only produces a single value estimate, it may not be beneficial for the users of the valuation report borrowing (Mallinson and French 2000: 15) and, more importantly, could be misleading (Nowak and Hnilica, 2012). To fully capture the variety of uncertainties, the output of valuation processes should provide a range, rather than a point, of value estimates (Prasetyo, 2018). The method to achieve this in this paper is outlined in the following section.

\section{Business Valuation for Tax Purposes in Indonesia}

In the Indonesian taxation system, business valuation has become increasingly critical. Reinforcement of valuation-based tax investigation and optimization of the role of valuation have been applied to raise tax revenue. The policy to increase the role of valuation for tax purposes has been announced in the Director General of Tax Circular Letter No 61/PJ/ 2015 concerning Optimization of Valuation for Disclosure of Tax Potential and Other Taxation Objectives. This regulation posits that the valuation for tax purposes is carried out to determine fair market value of valuation object at a particular time. Furthermore, the valuation for tax purposes should be performed objectively and professionally based on the valuation standard. Therefore, the purpose of the valuation activity is to determine the value that can be used as a basis for calculating the tax payable.

In regulating business valuation for tax purposes, the Indonesian government also ratifies the Director General of Tax Circular Letter No 54/PJ/2016 on Technical Instructions of Property Valuation, Business Valuation, and Intangible Assets Valuation for Taxation Purposes (SE 54/PJ/2016). It is stated that the business valuation for tax purposes in Indonesia aims to determine 
PLANNING MALAYSIA

Journal of the Malaysia Institute of Planners (2021)

the amount of a certain type of value in a given moment of a business entity. For tax purposes, business valuation measures, for instance, the value of transfer of assets to the company as a substitute for shares or equity participation; the value of transfer of assets to shareholders, allies, or members of a company; the value of sales, purchases, or transfers of assets in the form of a company between parties that have a special relationship; or the value of the transfer of assets in the form of a company in the context of liquidation, merger, consolidation, expansion, splitting or business takeover.

According to SE $61 / \mathrm{PJ} / 2016$, the tax valuer can select from several approaches, including income approach, to conduct a business valuation. The income approach valuation allows the tax valuer to apply either Discounted Cash Flow (DCF) Method or Capitalization of Income Method. The regulation also stipulates that the Estimated Value (output of business valuation for tax purposes) in the valuation report must be expressed in a single value (single amount). An example of the output of business valuation for tax purposes using DCF Method is presented in Figure 2.

\begin{tabular}{|c|c|c|c|c|c|c|c|}
\hline Discounted Cash Flow & Present & $T+1$ & $T+2$ & $T+3$ & $T+4$ & $T+5$ & Terminal \\
\hline $\begin{array}{l}\text { Unlevered FCF } \\
\text { (Entry)/Exit }\end{array}$ & & (69.181.430.858) & $(6.136 .528 .941)$ & 1.774.284.943 & 22.006 .852 .966 & 40.877 .622 .094 & $\begin{array}{l}\text { Average Exit } \\
672.438 .950 .350\end{array}$ \\
\hline Transaction CF & & $(69.181 .430 .858)$ & $(6.136 .528 .941)$ & 1.774.284.943 & 22.006 .852 .966 & 40.877 .622 .094 & 672.438 .950 .350 \\
\hline \multicolumn{8}{|l|}{ Market Value } \\
\hline Enterprise Value $(11,51 \%)$ & & 403.744.592.362 & & & & & \\
\hline Present Cash Flow & & 61.945 .039 .704 & & & & & \\
\hline Company Value & & 465.689 .632 .066 & & & & & \\
\hline
\end{tabular}

Figure 2: DCF Method

\section{METHODOLOGY AND RESULT}

Figure 2 depicts a business valuation for tax purposes conducted by tax valuer using a DCF method. Figure 2 illustrates that the main inputs for the company estimated value are the expected future cash flow, the expected terminated value, and discount rates. The underlying assumptions to the calculations believed that the expected cash flow varied according to the appraiser's calculation, the expected terminated value was based on the predicted company performance, and the estimated discount rate was $11.51 \%$.

At this point, the element of judgment appraiser began to appear. The tax valuers predicted the expected cash flow and the expected terminate value, and estimated the future cash flow and future terminate value based on company performance in the past. This is also true for the discount rate. Based on the distribution of comparable data, we found that the capitalization rate was not exactly $11.51 \%$. The tax valuer chose $11.51 \%$ because it seemed an appropriate discount rate to represent the company, resulting in an equity value of IDR 466 billion. 
Kristian Agung Prasetyo, Adhipradana Prabu Swasito, Dhian Adhetiya Safitra

Uncertainty In Business Valuation: The Monte Carlo Approach

Therefore, these estimations, should be treated with caution due to the uncertainties involved in selecting the discount rate. To clarify the inclusion of judgement into the value calculations, the next sections elaborate the concept of probability using Scenario analysis and Monte Carlo simulation.

\section{SCENARIO ANALYSIS}

Scenario analysis is conducted to provide more comprehensive value information compared to the DCF approach (Prasetyo, 2018). As shown in Figure 2, the chosen discount rate is $11.51 \%$. A review of available data showed that the actual discount rate fluctuated between $7 \%$ and $13 \%$, so the selected discount rate was approximately in between. This arbitrary is stemmed from the inherent uncertain nature in the equity market and the likelihood of incomplete data provided by the taxpayers in their attempt to minimize tax payable.

The scenario analysis provides more comprehensive information than the conventional DCF approach as it uses three possible discount rates of $7 \%$, $11.51 \%$, and $13 \%$. The results are presented in Figure 3.

\begin{tabular}{|lrrrr|}
\hline \multicolumn{2}{|c}{ Scenario Summary } & & & \\
& Current Values: & Optimistic & Pesimistic \\
\hline Changing Cells: & & & \\
\hline Discount Rate & $11,51 \%$ & & $13 \%$ \\
\hline Result Cells: & & & \\
\hline Company ' \$D\$2 & 465.689 .632 .066 & 550.624 .015 .479 & 441.313 .271 .169 \\
\hline
\end{tabular}

Figure 3: Scenario Analysis Result

Although more comprehensive, it can still be asked on the decision to use only three rates. This is because there basically are an infinite number of rates between $7 \%$ and $13 \%$ that have the same probability of being 'the correct' discount rate. Accordingly, an infinite number of estimated values that share probability as 'the correct' equity value also exists. The procedure to take this fact into account is presented in the next section.

\section{Monte Carlo Simulation}

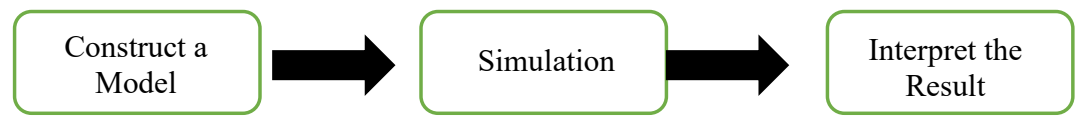

Figure 4: Monte Carlo Simulation: Step by Step Source: Charnes (2012) 
The Monte Carlo simulation is a popular tool in calculating risk and uncertainty in a model (Nowak and Knilica, 2012), mostly due to its strength, relative simplicity, and flexibility (Christie, 2018). The simulation runs a large number of possible scenarios. If the scenario analysis only produces three value points, the simulation technique produces thousands of estimated company values. The input is taken randomly between certain values based on a certain statistical distribution. The result is normally presented in the form of frequency distribution, enabling the valuer to calculate the probability of certain equity value to occur. The sequence of simulation steps is illustrated in Figure 4.

Table 1: Summary of Monte Carlo Simulation

\begin{tabular}{lrcrrrr} 
Variable & Mean & SE Mean & StDev & Minimum & Q1 & Median \\
\hline VALUE & $4.69107 \mathrm{E}+11$ & 116048802 & 25949301105 & $4.11039 \mathrm{E}+11$ & $4.50103 \mathrm{E}+11$ & $4.67639 \mathrm{E}+11$ \\
Variable & Q3 & Maximum & & & & \\
\hline VALUE & $4.87173 \mathrm{E}+11$ & $5.37908 \mathrm{E}+11$ & & & &
\end{tabular}

Referring back to the scenario analysis in the preceding section, this study used three discount rates parameters of 7,59\%, 11,51\%, and $13 \%$. The appropriate distribution for this type of known parameters is the triangular distribution (Prasetyo, 2018). Here, the calculation was repeated 50 thousand times to obtain consistent results (French and Gabrielli, 2004). Table 1 presents the summary of simulation results calculated using Minitab 19.2.

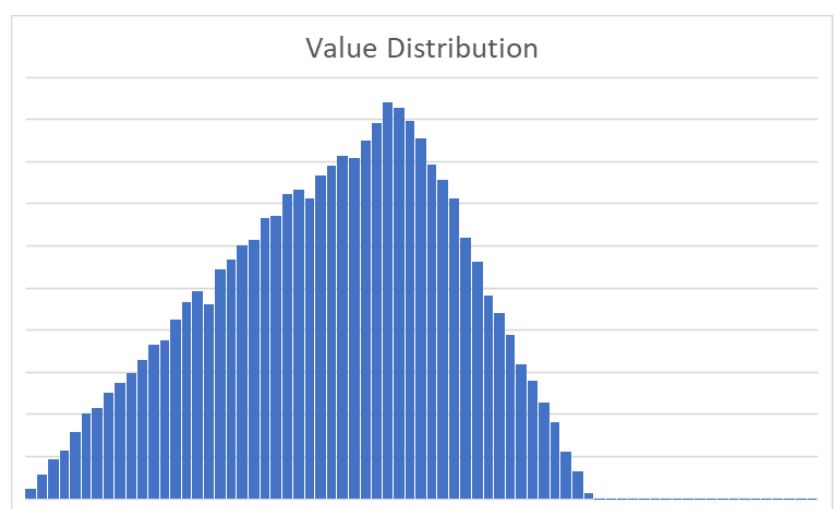

Figure 5: Value Distribution 
Kristian Agung Prasetyo, Adhipradana Prabu Swasito, Dhian Adhetiya Safitra Uncertainty In Business Valuation: The Monte Carlo Approach

\begin{tabular}{|c|r|}
\hline PERCENTILE & ESTIMATED VALUE \\
\hline $0 \%$ & 411.567 .943 .453 \\
\hline $5 \%$ & 424.640 .999 .887 \\
\hline $10 \%$ & 430.971 .556 .361 \\
\hline $15 \%$ & 435.370 .332 .807 \\
\hline $20 \%$ & 439.130 .899 .435 \\
\hline $25 \%$ & 442.501 .399 .108 \\
\hline $30 \%$ & 445.814 .508 .251 \\
\hline $35 \%$ & 448.831 .599 .431 \\
\hline $40 \%$ & 451.451 .399 .332 \\
\hline $45 \%$ & 454.395 .034 .436 \\
\hline $50 \%$ & 457.075 .469 .892 \\
\hline $55 \%$ & 459.680 .779 .833 \\
\hline $60 \%$ & 462.011 .554 .322 \\
\hline $65 \%$ & 464.272 .211 .100 \\
\hline $70 \%$ & 466.449 .470 .903 \\
\hline $75 \%$ & 468.755 .277 .254 \\
\hline $80 \%$ & 471.415 .882 .791 \\
\hline $85 \%$ & 474.315 .902 .394 \\
\hline $90 \%$ & 477.678 .791 .289 \\
\hline $95 \%$ & 481.804 .813 .458 \\
\hline $100 \%$ & 530.241 .818 .827 \\
\hline
\end{tabular}

Figure 6: Estimated Value in Percentile

\section{Interpretation}

Equity value that is estimated to reach IDR 466 billion (Figure 3) should be treated with caution as it is calculated based on certain assumptions. One notable assumption is the constant discount rate of $11.51 \%$. A quick look at the current business situation points to a fact that this assumption violates reality, as one can easily find that the discount rate fluctuates between $7 \%$ to $13 \%$. This is the basis of the scenario analysis in Figure 3. A major advantage of this technique is the inclusion of three scenarios of an optimist, a pessimist, and a most likely. Each uses three different discount rates of $7 \%, 13 \%$, and $11.5 \%$ per annum, resulting in three possible equity values, rather than one as calculated by the traditional DCF (Figure 3).

Readers should be aware that despite an improvement from the traditional DCF, Scenario Analysis could include plenty of possible discount rates between $7 \%$ and $13 \%$ that should not be ignored. Addressing this issue, Monte Carlo simulation demonstrates that the average of value estimate is IDR 469 billion (SD of IDR 26 billion) and the equity value is unlikely less than IDR 411 billion or more than IDR 538 billion.

This result can find immediate impact in the Indonesian tax office where profit from equity transactions between entities is taxed. A carefullycrafted simulation model can be used to assess whether or not the amount reported by a taxpayer is reasonable. For the context in this paper, if the model is used for 
PLANNING MALAYSIA

Journal of the Malaysia Institute of Planners (2021)

income tax purposes, a taxpayer who reports an equity transaction below IDR 411 billion clearly warrants further scrutiny. It is, by no means, a guarantee of a tax evasion scheme, but provides a basis for further investigation by tax auditors.

The simulation also provides a safe harbor where the equity value estimates can be considered truthful. This can be seen in Figure 6. These indicators generally partition the dataset into four distinct parts after it is arranged in ascending order. Q1 and Q3 each indicates the first and last quarter while Q2 normally is the middle of all dataset. A generally accepted view in taxation guides, such as the OECD's transfer pricing guidelines, mentions that an arm's length value is one that lies between Q1 and Q3. Hence, if the taxpayer reports a transaction value of IDR 455 billion, this transaction can be considered at arm's length and no further actions are required. On the other hand, if the taxpayer reports IDR 400 billion, the tax auditor needs to be weary as it clearly falls below the lower bound of the acceptable equity value estimate.

\section{CONCLUSION}

Valuation is an estimate of the most probable transaction price. Models are thus used to arrive at a value estimate. One of these is the DCF technique, often used in a company's equity valuation. A notable weakness of this technique is the use of a static discount factor. While a discount factor is generally probabilistic in nature, the DCF ignores this.

This paper aims to provide a way to address this issue using Monte Carlo simulation. While it is not new, the use of this technique is gaining popularity due to the rapid development of personal computers.

Using this technique, it is possible for valuers to present the probabilistic nature of business valuation in their reports. For tax purposes, this technique can find immediate application in assessing whether taxpayers report arm's length price of equity transactions in their tax return.

\section{REFERENCES}

Allingham, M. G. and A. Sandmo (1972). "Income Tax Evasion: A Theoretical Analysis." Journal of Public Economics 1(3-4): 323-338.

Bancel, F., \& Mittoo, U. R. (2014). The gap between the theory and practice of corporate valuation: Survey of European experts. Journal of Applied Corporate Finance, 26(4), 106-117.

Charnes, John. 2012. Financial Modeling with Crystal Ball and Excel (Wiley).

Christie, D. S. (2018). Build your own Monte Carlo spreadsheet. Spreadsheets in Education, 11(1), 4672.

Emirzon, Joni. 2005. 'Kode Etik dan Permasalahan Hukum Jasa Penilai Dalam Kegiatan Bisnis di Indonesia', Jurnal Manajemen dan Bisnis Sriwijaya, 3: 1-13.

Fernández, P. (2007). Company valuation methods. The most common errors in valuations. IESE Business School, 1-27. 
Kristian Agung Prasetyo, Adhipradana Prabu Swasito, Dhian Adhetiya Safitra

Uncertainty In Business Valuation: The Monte Carlo Approach

French, Nick, dan Laura Gabrielli. 2004. 'The Uncertainty of Valuation', Journal of Property Investment \& Finance, 22: 484-500.

French, Nick. 2004. 'The Valuation of Specialised Property: A Review of Valuation Methods', Journal of Property Investment \& Finance, 22: 533-41.

IVSC. 2010. 'Valuation Uncertainty', International Valuation Standards Council, https://www.ivsc.org/files/file/download/id/296.

Ja'afar, N. S, Mohamad, J. (2021). Application of machine learning in analysing historical and non-historical characteristics of heritage pre-war shophouses. Planning Malaysia, 19(2), 72-84. http://dx.doi.org/10.21837/pm.v19i16.953

Jansen van Vuuren, David. 2017. 'Valuation Paradigm: A Rationality and (Un)Certainty Spectrum', 35: 228-39.

Kahr, Joshua, dan Michael C. Thomsett. 2006. Real Estate Market Valuation and Analysis (Wiley).

Köseoğlu, Sinem \& Almeany, Saad. (2020). Introduction to Business Valuation. 10.4018/978-1-7998-1086-5.ch001.

Kummerow, Max. 2002. 'A Statistical Definition of Value', Appraisal Journal, 70: 407.

Laughton, D., Guerrero, R., \& Lessard, D. (2008). Real Asset Valuation: A Back-tobasics Approach. Journal of Applied Corporate Finance, 20(2), 46-65.

Lincoln, Yvonna S., dan Egon G. Guba. 1985. Naturalistic Inquiry (SAGE Publications).

Mallinson, Michael, dan Nick French. 2000. 'Uncertainty in Property Valuation-The Nature and Relevance of Uncertainty and How It Might Be Measured and Reported', Journal of Property Investment \& Finance, 18: 13-32.

Mohammad, N. E, Mohd Ali, H, \& Haryati Jasimin, T. (2018). Valuer's behavioural uncertainties in property valuation decision making. Planning Malaysia, 16(1), 239-250. https://doi.org/10.21837/pmjournal.v16.i5.428

Nowak, O. N. D. R. E. J., \& Hnilica, J. I. ̌̌. Í. (2012). Business Valuation under Uncertainty. In Proc. of the 5th WSEAS Int. Conf. on Business Administration (pp. 87-92).

Prasetyo, K. A. (2018). Penentuan Unsur Ketidakpastian Dalam Penghitungan Estimasi Nilai Pasar Properti Dengan Menggunakan Pendekatan Pendapatan: Catatan Praktisi. Simposium Nasional Keuangan Negara, 1(1), 58-78.

Sayce, Sarah, Judy Smith, Richard Cooper, dan Piers Venmore-Rowland. 2009. Real Estate Appraisal: From Value to Worth (Wiley).

Received: $12^{\text {th }}$ July 2021. Accepted: $17^{\text {th }}$ Sept 2021 